\title{
Local Wisdom ( Sukuraga Puppets) Android Application as a Media Literacy Learning
}

\author{
I Nurasiah $^{1}$, A Juliansyaha ${ }^{2}$, D Lyesmaya ${ }^{3}$ \\ \{iisnurasiah@ummi.ac.id ${ }^{1}$, ariszulianlsyah@ummi.ac.id ${ }^{2}$, lyesmaya_dyah@ummi.ac.id ${ }^{3}$ \} \\ ${ }^{1,2,3}$ Universitas Muhammadyah Sukabumi, Indonesia
}

\begin{abstract}
The purpose of this study was to determine the effectiveness of the application of Android Sukuraga as a media literacy in the study. The subject of this study was five validation experts and the teachers of State Elementary School in Sukabumi City consisting of 300 teachers. The results of this study indicate that (1) the process of developing media literacy includes 5 grades (2) android application materials local wisdom literacy was feasible to use, (3) teaching materials based on android applications based on local wisdom-charged literacy were effective used.
\end{abstract}

Keywords: local wisdom, android application, media literacy

\section{INTRODUCTION}

In industry 4.0, the era of mass media plays an important role in life so that each individual can not be separated from its influence. People continue to use social media such as android as part of the means of life. Rapid advances in technology can dramatically change human lives. Individuals experience a technology-driven environment not only in daily life but also in professional life. The 4.o industry era was created by Schwab in 2016 and mentions that era 4.0 was hyperconnected or became hyper-intelligent because of large data or artificial intelligence [1] so that in South Korea (2014), Cuba (2016), USA ( 2000) has included the ability of media literacy or digital literacy into the curriculum in schools ranging from kindergarten to college.

Using android media as a learning media in the classroom and outside the classroom facilitates students to get knowledge more quickly and broadly.[2] In this context, the use of mobile devices in the learning environment can be seen as a component that can improve efficiency in the teaching-learning process. That important to evaluation android by based learning environment as an opportunity to achieve the integration of mobile learning technologies and mobile applications into education So the integration technology into education very necessary to support and update the media to support professional teachers so as to improve literacy in a manner digital for students. [3]

The history of media literacy began in 1964 when UNESCO developed a model of media education programs that would be carried out throughout the world. Since then various countries have begun to pay attention to media literacy, one of which is to do media literacy or media education through formal and no- formal education channels. [4]

Literacy very important to be applied in formal and non-formal, where the two places have different cultures and habits each other's culture of each country. (Yer, 2011) [5] L iterations the source of technology from communication, the code used, the message produced and the 
selection, interpretation and, impact of the message. Silverblat identified five elements of media literacy, namely: 1. Awareness of the impact of media on individuals and society. 2. Understanding the process of mass communication . 3. Development of strategies for analyzing and discussing media messages. 4. Awareness of media content as a text that gives understanding our culture and ourselves. 5 Enhanced understanding of pleasure, understanding and, appreciation of media content. [6]

Eshet-Alkalai (2012) argues that digital literacy as a technical ability that requires more than intelligence to use devices but also requires technical and procedural, cognitive, and socialemotional skills needed to live, learn, and work in a digital society [6]

Therefore, one of the principles in media education or media literacy is to empower audiences. It is called empowering, because in Brow's view "media literacy is a new compass in navigating the world of media." Because, in Brow's assessment, "if people are not empowered, people will become victims of the media." The aim of media literacy is to give us greater control over interpretation because all media messages are the result of construction. With regard to the empowerment of media audiences to build this empowered audience, we will once again see the purpose and flow of media education to achieve medialiteracy. [7]

In terms of the objectives of media literacy, there are two different views. The first view, called protectionist groups, states that media education is intended to protect citizens as media consumers from the negative effects of media literacy. The second view, called preparations, states that media literacy is an effort to prepare citizens to live in a media-tight world in order to become a critical media consumer. That is, in the eyes of the preparatory group, the general public needs to be equipped with the competence of media literacy to benefit from the presence media.

Local wisdom is a manifestation of cultural teachings that are presented by a local community and can be used as a filter to absorb and process foreign cultures according to their own character and abilities. Foreign culture here includes foreign to the public through media . Cultural values and local wisdom that owned by the community can be used as a basis when interpreting the experiences they have gained from the mass media, so that the social behavior that is formed is social behavior that is in accordance with the culture of the community rather than social behavior based on media culture . [8]

This cultural wealth and potential must be developed and maintained. Because cultural property owned is identity and state assets [7] Recently, the interest of highly capable students has increased throughout the world, and more and more research is paying attention to their characteristics and meeting their cognitive, emotional, and social needs. This interest arises from the difficulties faced by superior students in their educational settings, for example, traditional strategies used by teachers do not challenge their abilities or fulfill their desire to continue. Consequently, researchers in Texas recommend that preparing an educational environment that supports these students reach their full potential [9]

Laying the principles of cultural wealth and potential in Sukabumi must be done early in school. Elementary Schools as formal educational institutions responsibility to realize the goals of national education also have an obligation to shape the identity of children as part of their cultural environment. Therefore, elementary schools require the development of education in accordance with the characteristics of cultural wealth in the school environment

One of the riches of the local culture of Sukabumi is Wayang Sukuraga. Sukuraga Puppet is different from wayang from other countries. The characters in the Sukuraga Puppet part of our body namely the Five Senses (eyes, mouth, ears, nose ), hands and feet. The Sukuraga is made by Effendi as an artist who wants to be a puppet shaped art but not forgetting the creator's 
natural nature. So that the puppets are made in different forms from wayang in general. Effendi created a puppet that can teach how humans to always remember the Creator and learn to understand yourself (which is present in humans) before understanding the ain in $\mathrm{k}$ e wildlife. Wayang Sukraga is full of education because every character in Wayang Sukuraga reminds us of the functions and meanings of the five senses that God has given us.

Based on all $t$ moans above the researchers in collaboration with Effendi creator of Puppet Sukuraga to create applications Puppet Sukuraga form of Wayang Sukuraga in the form of Android, so the application can be enjoyed and ranging from the children to adults, according to the needs of the times era 4.0 that life human today is not free from the use of Android. Sukuraga application is a sukuraga puppet application in the form of an android that can be downloaded via Playstore. This application consists of contents: simulation , knowledge, info, and quizzes. Simulation content teaches users to play sukuraga puppets from each character and can replace the screen background with historical places in the city of Sukabumis such as the fighting building, the monument, the kotabumiku monument, and the town hall. The Knowledge Section consists of Sukuraga, Philosophy, Artists and Literature , info content contains historical information from wayang sukuraga and Quiz content contains games in the form playstore user understanding of Wayang Sukuraga through questions and scores

In accordance with research conducted by Nthuli (2017) technology has changed the science of educating at an early age so that today's society needs media education based on local wisdom, so that the culture or wealth of a nation can be maintained and enriched by not forgetting the elements of the nation's cultural richness according to wisdom locally owned. [10] The era of globalization requires us to always increase media literacy and can start from the environment of children. As research conducted in Ates (2017) that the advancement of media literacy will change the human mind quickly so needs local wisdom-based media so that citizens are not affected by globalization is not in accordance with the cultural values of the nation. [11]

\section{REASEARCH METHOD}

This study uses a qualitative approach to the resulting data in the form of words, sentences and images to explore how social reality occurs by describing variables that are relevant to the problem and unit study, this case is how to study the case studies studied. The initial stage of the research methodology is to determine the type of research, which is based on the research method being carried out. The research method that will be carried out using the case study research method because the research, there are many problems arising from the exposure of the android application media which the result in changes in the order of people's lives so that media literacy is needed for education. [12]

The case study itself, according to Stake, is a research method that explains the decisions in the study then implements and after that sees the results. The type of case study research itself consists of three types, namely (1) intrinsic case study, if the study is aimed at gaining a better understanding of a particular case; (2) instrumental case study, if a particular case is examined with the main objective of gaining an understanding of an issue or to obtain generalizations so that it is supportive and clarifying other cases; and (3) multiple case study or collective case study, if several cases are examined together to explore a phenomenon, population, or general condition. [13]

\section{RESULTS AND DISCUSSION}

The results of this study began with the training to assist the use of Sukuraga Android media for 3 months starting from May to August 2019 to elementary school teachers in the City of 
Sukabumi. The teacher gives an assessment of the use of the sukuraga android application in the classroom. Then the data were analyzed by 1 . Awareness will be the impact of the media on individuals and society. 2. Understanding the process of mass communication . 3. Development of strategies for analyzing and discussing media messages. 4. Awareness of media content as a text that gives culture and ourselves. 5 Enhanced understanding of pleasure, understanding and, appreciation of media content.

From the results of observation and interviews obtained that the level of awareness of the impact of individuals and society, they better understand how important the values that exist in the local wisdom of wayang sukuraga, in the use of the senses, after the eyes (panon) see the mouth moves after thinking and so on

The second level of understanding of the communication process, obtained data from 300 teachers who attended the workshop 70 percent can use applications with good communication to the audience, namely students, students also look enthusiastic about learning, but 30 percent do not understand its use because the age factor of participants aged over 55 years so it requires patience and patience to use the Android app.

The third level 95 percent of teachers can analyze the use of applications and give messages according to media sukuraga application. The message conveyed contain moral education for students, and students also give offered are a message back using the existing contents application

The fourth level was obtained as much as 80 percent of participants understood the messages that were expected from the wayang sukuraga as items from local wisdom, that the wayang sukuraga was unique or different from other pupets in Indonesia starting from the shape, color, character, and role of the puppet characters.

Last, teachers can innovate the use of applications by adding messages through stories from puppet figures Sukuraga and inviting students to preserve local wisdom by making other media besides android applications such as hand dolls, handicrafts, and literary works, so students more lively messages from characters wayang sukuraga.

From the above data, it is revealed that local wisdom has a positive message, especially a moral message that can increase the moral intelligence that uses it. Local wisdom can be preserved by incorporating it into the curriculum by collaborating with the local government, especially the education office, so that cultural preservation which is full of moral education can be maintained. This is in line with research conducted by Chusorn (2014) [14] That cultural preservation can be realized by using local wisdom in school curricula to introduce culture early on. And the introduction of media literacy can be introduced from an early age like research conducted by Dileck Altun (2018) [15].

\section{CONCLUSIONS}

Based on the above data it can be concluded that the puppet android application sukuraga as local wisdom are positive, contributing to improved literacy media on society in general and education in particular. Sukuraga android application test searches obtained data that shows the effectiveness of the use of applications in learning to improve media literacy as educators and educated students, and the meaning or message in the local wisdom of Sukabumi, Wyang Sukurga, can improve moral intelligence and media literacy in the environment people in general and special education. 


\section{REFERENCES}

[1] K. T. Kim, "The structural relationship among digital literacy, learning strategies, and core competencies among south Korean college students," Educ. Sci. Theory Pract., vol. 19, no. 2, pp. 3-21, 2019.

[2] Ş. Kocakoyun and H. Bien, "Development and evaluation of educational android application," Cypriot J. Educ. Sci., vol. 12, no. 2, pp. 58-68, 2017.

[3] C. Chang, Y. Lian, D. Zhang, and S. Wang, "The Influence of Students Information Literacy Competency on Creativity under the Regulation of Classroom Climate," no. July, pp. 1551-1560, 2016.

[4] M. Ivanović, "Development of Media Literacy - An Important Aspect of Modern Education," Procedia - Soc. Behav. Sci., vol. 149, pp. 438-442, 2014.

[5] Y. J. Thao, "Bicultural Literacy Curriculum," vol. 3, no. 2, pp. 251-255, 2012.

[6] R. Mulyasih, "Pentingnya Literasi Media Bagi Kaum Perempuan," LONTAR J. Ilmu Komun., vol. 4, no. 3, 2017.

[7] Suswandari, "Incorporating beliefs, values and local wisdom of Betawi culture in a character-based education through a design-based research," Eur. J. Contemp. Educ., vol. 6, no. 3, pp. 574-585, 2017.

[8] P. T. Anggraini, "Character and Local Wisdom-Based Instructional Model of Bahasa Indonesia in Vocational High Schools," J. Educ. Pract., vol. 8, no. 5, pp. 23-29, 2017.

[9] A. Kuyatt, G. Holland, and D. Jones, "An Analysis Of Teacher Effectiveness Related To Technology Implementation In Texas Secondary Schools," Contemp. Issues Educ. Res., vol. 8, no. 1, pp. 63-70, 2015.

[10] E. Ntuli, "Evaluation of Instructional Technology: A Case Study of Early Childhood Teacher Candidates," Open J. Educ. Res., vol. 1, no. 1, pp. 1-14, 2017.

[11] H. K. Ateş and N. Afat, "A case study investigating the language development process, early literacy experiences and educational problems of a gifted child," J. Educ. Gift. Young Sci., vol. 6, no. 4, pp. 36-71, 2018.

[12] "ERIC ED573597_ Introduction_ Qualitative Approaches to Research on Plurilingual Education_ERIC__ Free Download, Borrow, and Streaming _ Internet Archive." .

[13] M. Rosenthal, "Qualitative research methods: Why, when, and how to conduct interviews and focus groups in pharmacy research," Curr. Pharm. Teach. Learn., vol. 8, no. 4, pp. 509-516, 2016.

[14] D. Dahliani, "Local wisdom in built environment in globalization era," Int. J. Educ. Res., 2015.

[15] R. Rahim, K. Saddhono, and D. Sulaksono. Unified modeling language as a design of interactive ebook application for android. Journal of Advanced Research in Dynamical and Control Systems. vol. issue. 5 pp. 634-637, 2019 
